\title{
KEBERLAKUAN PUTUSAN PRAPERADILAN DALAM MEMERINTAHKAN PENYIDIK UNTUK MENETAPKAN STATUS TERSANGKA (STUDI KASUS PUTUSAN NOMOR: 24/Pid/Pra/2018/PN.Jkt.Sel.)
}

\author{
Rugun Romaida Hutabarat ${ }^{1}$, Jeffri Pri ${ }^{2}$, Edwin Tunggawan ${ }^{3}$, Kennedy Kenny ${ }^{4}$ \\ Fakultas Hukum Universitas Tarumanagara \\ Jalan Letjen S Parman, No. 1, Gogol, Jakarta Barat, 11440 \\ ${ }^{1}$ Email: rugun@fh.untar.ac.id \\ 2Email: jeffmartono@gmail.com \\ ${ }^{3}$ Email: edwins.tunggawan@gmail.com \\ [Email: Kennedyknny@gmail.com
}

\begin{abstract}
Under Article 77 of Law of The Republic Indonesia Number 8 of 1981 Concerning Criminal Procedure Law or Indonesia's Code of Criminal Procedure stated that a district court can conduct pretrial hearing to determine whether an arrest or detention carried out legally. The court also adjudicate the proprietry of the cessation of an investigation prosecution. The pretrial hearing decision number 24/Pid/Pra/2018/PN.Jkt.Sel was the breakthrough, because for the first time in Indonesia, judge of the pretrial hearing decided that to order the investigator of the Corruption Eradication Commision to firm the suspect status to Boediono, Muliawan D Hadad, Raden Pardede and friends in the corruption case of the Bank of Century. Based on the law principal, res judicata pro veritate habetur, means that the judge decision is determined to be right, this decision has to be conducted with no exception.
\end{abstract}

Keywords: pretrial hearing, suspect status, res judicata pro veritate habetur

\section{ABSTRAK}

Berdasarkan Pasal 77 Republik Indonesia Nomor 8 Tahun 1981 tentang Hukum Acara Pidana atau Hukum Acara Pidana Indonesia menyatakan bahwa pengadilan negeri dapat melakukan persidangan praperadilan apakah penangkapan atau penahanan dilakukan secara legal. Pengadilan juga mengadili putusan eksklusif investigasi penuntutan. Keputusan sidang praperadilan nomor 24 / Pid / Pre / 2018 / PN.Jkt.Sel adalah terobosan, karena untuk pertama kalinya di Indonesia, hakim sidang praperadilan memutuskan bahwa untuk memerintahkan penyelidik Komisi Pemberantasan Korupsi untuk mengukuhkan status tersangka kepada Boediono, Muliawan D Hadad, Raden Pardede dan kawan-kawan dalam kasus korupsi Bank of Century. Berdasarkan prinsip hukum, res judicata pro veritate habetur, keputusan hakim ditentukan benar, keputusan ini harus dilakukan tanpa kecuali.

Kata kunci: pemeriksaan praperadilan, status tersangka, res judicata pro veritate habetur

\section{PENDAHULUAN}

Undang-Undang Dasar Negara Republik Indonesia 1945 menjelaskan dengan tegas bahwa Negara Republik Indonesia berdasarkan atas hukum (rechsstaat), tidak berdasarkan atas kekuasaan belaka (machstaat). ${ }^{1}$ Hal ini berarti bahwa Negara Republik Indonesia adalah Negara hukum yang demokratis berdasarkan Pancasila dan Undang-Undang Dasar Negara Republik Indonesia 1945 yang menjunjung tinggi hak asasi manusia serta menjamin segala warganegara bersamaan kedudukannya di dalam hukum dan pemerintahan. Atas dasar itulah sangat jelas bahwa penghayatan, pengamalan

\footnotetext{
${ }^{1}$ Hal ini secara tegas dinyatakan dalam Pasal 1 ayat 3 Undang-Undang Dasar Negara Republik Indonesia 1945, yang menyatakan bahwa Negara Indonesia adalah Negara hukum.
} 
dan pelaksanaan hak asasi manusia maupun hak serta kewajiban warganegara untuk menegakkan keadilan tidak boleh ditinggalkan oleh setiap warganegara, setiap penyelenggara Negara, setiap lembaga kenegaraan dan lembaga kemasyarakatan baik di pusat maupun di daerah yang perlu terwujud dalam dan adanya hukum acara pidana. Terkait hal tersebut, hukum acara pidana nasional wajib didasarkan pada falsafah atau pandangan hidup bangsa dan Negara, yang mana seluruh ketentuan materi pasal atau ayat tercermin perlindungan terhadap hak asasi manusia serta kewajiban warganegara.

Ruang lingkup hukum acara pidana di Indonesia meliputi mencari kebenaran ${ }^{2}$, penyelidikan ${ }^{3}$, penyidikan, dan pelaksanaan pidana (eksekusi) oleh jaksa. Dengan terciptanya Undang-Undang Republik Indonesia Nomor 8 Tahun 1981 tentang Hukum Acara Pidana yang selanjutnya disebut dengan Kitab Undang-Undang Hukum Acara Pidana (KUHAP), berarti untuk pertama kalinya bangsa Indonesia melakukan kodifikasi dan unifikasi hukum yang lengkap, meliputi seluruh proses pidana dari awal (mencari kebenaran) sampai pada kasasi di Mahkamah Agung. Lebih daripada itu, bahkan sampai kepada tahap Peninjauan Kembali (PK).

KUHAP tidak memberikan definisi tentang hukum acara pidana, tetapi bagian-bagiannya seperti penyidikan, penuntutan, mengadili, praperadilan, putusan pengadilan, upaya hukum, penyitaan, penggeledahan, penangkapan, penahanan, dan lain-lain yang diberi definisi dalam Pasal 1 yang berbicara tentang ketentuan umum. ${ }^{4}$ Adapun definisi hukum acara pidana menurut Luhut Pangaribuan, adalah ketentuan normatif sistem peradilan pidana. Sedangkan menurut Wirjono Prodjodikoro, hukum acara pidana berhubungan erat dengan adanya hukum pidana, maka dari itu merupakan suatu rangkaian peraturan yang memuat cara bagaimana badan-badan pemerintah yang berkuasa, yaitu kepolisian, kejaksaan dan pengadilan harus bertindak guna menapai tujuan Negara dengan mengadakan hukum pidana. ${ }^{5}$ Sistem peradilan pidana menganut konsep bahwa kasus pidana merupakan sengketa antara individu dengan masyarakat (publik) dan sengketa itu akan diselesaikan oleh pemerintah sebagai wakil dari publik. ${ }^{6}$

Sistem peradilan pidana Indonesia secara normatif diatur dalam KUHAP yang diharapkan sebagai kodifikasi hukum. Dengan demikian KUHAP dan himpunan peraturan pelaksanaanya menjadi diperlukan sebagai kelengkapan kodifikasi dalam praktik dalam satu kompilasi. ${ }^{7}$

Dalam hukum acara pidana di Indonesia, setelah KUHAP diundangkan pada 31 Desember 1981, ada dikenal sebuah tahapan yang bernama praperadilan. Di Eropa dikenal lembaga semacam ini, tetapi fungsinya memang benar-benar melakukan pemeriksaan pendahuluan. Jadi fungsi hakim komisaris

\footnotetext{
${ }^{2}$ Andi Hamzah, Hukum Acara Pidana Indonesia (Edisi Kedua). Jakarta: Sinar Grafika, 2015. Hal 8.

Menyatakan bahwa Van Bemmelen mengemukakan 3 (tiga) fungsi hukum acara pidana yaitu sebagai berikut:

1. Mencari dan menemukan kebenaran;

2. Pemberian putusan oleh hakim; dan

3. Pelaksanaan putusan.
}

Dari ketiga fungsi di atas, yang paling penting karena menjadi tumpuan kedua fungsi berikutnya adalah "mencari kebenaran", karena setelah menemukan kebenaran yang diperoleh melalui alat bukti dan bahan bukti itulah, hakim akan sampai kepada putusan (yang seharusnya) adil dan tepat, yang kemudian dilaksanakan oleh jaksa.

${ }^{3}$ Penyelidikan pada merujuk Pasal 1 ayat 5; penyidikan merujuk pada Pasal 1 ayat 2; dan pelaksanaan pidana (eksekusi) oleh Jaksa merujuk pada Pasal 1 ayat 6 huruf a Undang-Undang Republik Indonesia Nomor 8 Tahun 1981 tentang Hukum Acara Pidana atau yang selanjutnya akan disebut dengan Kitab Undang-Undang Hukum Acara Pidana (KUHAP).

${ }^{4}$ Andi Hamzah, Hukum Acara Pidana Indonesia (Edisi Kedua). Jakarta: Sinar Grafika, 2015. Hal. 4.

${ }^{5}$ Wirjono Prodjodikoro, Hukum Acara Pidana di Indonesia. Bandung: Sumur Bandung, 1974. Hal. 13.

${ }^{6}$ Luhut M.P. Pangaribuan, Hukum Acara Pidana: Surat-Surat Resmi di Pengadilan oleh Advokat, Praperadilan, Eksepsi, Pledoi, Duplik, Memori Banding, Kasasi, Peninjauan Kembali. Jakarta: Djambatan, 2005. Hal. 1.

${ }^{7}$ Ibid. hal 2. 


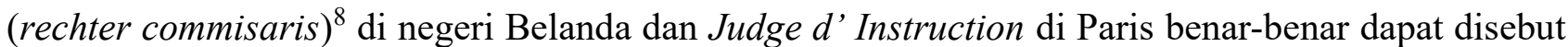
praperadilan, karena selain menentukan sah tidaknya penangkapan, penahanan, penyitaan juga melakukan pemeriksaan pendahuluan atas suatu perkara. Akan tetapi menurut KUHAP, wewenang praperadilan terbatas ${ }^{9}$. Wewenang itu untuk memutuskan apakah suatu daya paksa yang merupakan wewenang daripada aparat penegak hukum dalam melakukan wewenangnya menjadi sah atau tidak, yang mana hal tersebut diputuskan oleh seorang hakim tunggal yang ditunjuk oleh ketua Pengadilan Negeri dan dibantu oleh seorang panitera, sebagaimana hal ini dinyatakan pada Pasal 78 Ayat 2 KUHAP.

Terkait dengan putusan Pengadilan Negeri Jakarta Selatan Nomor 24/Pid/Pra/2018/PN.Jkt.Sel., yang memerintahkan Komisi Pemeberantasan Korupsi (KPK) untuk menetapkan mantan Wakil Presiden Boediono ${ }^{10}$ yang saat itu menjabat sebagai wakil Gubernur Bank Indonesia, serta beberapa rekannya agar menjadi tersangka. Sidang yang dipimpin oleh hakim tunggal Effendi Mukhtar, juga memerintahkan Komisi Pemberantasan Korupsi (KPK) untuk melanjutkan penyidikan kasus skandal Bank Century. Dalam putusan nomor 24/ Pid.Pra/2018 PN Jakarta Selatan tersebut yang mana pihak pemohon adalah Perkumpulan Masyarakat Anti Korupsi Indonesia (MAKI), sedangkan termohonnya adalah KPK, merupakan hal-hal yang berada di luar ruang lingkup objek dari pada praperadilan itu sendiri, yang mana hal tersebut diatur dalam Pasal 77 Kitab Undang-Undang Hukum Acara Pidana (KUHAP), maupun putusan Mahkamah Konstitusi terkait praperadilan.

Berdasarkan hal teserbut di atas, maka selanjutnya dibahas dalam tulisan ini mengenai bagaimana konsekuensi hukum daripada putusan praperadilan, yang mana hal itu berada di luar ruang lingkup objek praperadilan sebagaimana diatur pada Pasal 77 Kitab Undang-Undang Hukum Acara Pidana (KUHAP) maupun Putusan Mahkamah Konstitusi (MK) Nomor 21/PUU-XII/2014.

\section{METODE PENELITIAN}

Metode yang digunakan adalah yuridis normatif yaitu penelitian kepustakaan (Librarian Research), berupa penelitian terhadap data. Sedangkan data primer dalam penelitian ini hanya sebagai data penunjang. ${ }^{11}$ Penelitian ini juga menggunakan beberapa pendekatan yaitu pendekatan perundangundangan (statute approach) dilakukan dengan menelaah semua undang-undang dan regulasi yang bersangkut paut dengan isu hukum yang ditangani ${ }^{12}$. Selain itu pendekatan yang digunakan adalah pendekatan konseptual, yang mana hal ini dilakukan manakala peneliti tidak beranjak dari aturan yang ada, hal ini dilakukan karena memang belum atau tidak ada aturan hokum untuk masalah yang dihadapi adapun dalam menggunakan pendekatan ini, merujuk kepada prinsip-prinsip hukum ${ }^{13}$. Prinsip-prinsip ini dapat diketemukan dalam pandangan-pandangan sarjana ataupun doktrin-doktrin hukum. Hasil penelitian ini bersifat deskriptif analitis dan preskriptif. Deskriptif analitis yaitu suatu penelitian yang dilakukan secara deskriptif, terbatas pada usaha mengungkapkan suatu masalah dan keadaan sebagaimana adanya, sehingga hanya bersifat mengungkap atau memaparkan suatu peristiwa

\footnotetext{
${ }^{8}$ Andi Sofyan, Abd. Asis, Hukum Acara Pidana Suatu Pengantar. Jakarta: Prenadamedia Group, 2014. Hal. 185.

${ }^{9}$ Andi Hamzah, Hukum Acara Pidana Indonesia (Edisi Kedua). Jakarta: Sinar Grafika, 2015. Hal. 187.

${ }^{10}$ Merupakan wakil Presiden pada pemerintahan Presiden Soesilo Bambang Yudhoyono (SBY), dengan masa jabatan 20 Oktober 2009 sampai dengan 20 Oktober 2014. Pada saat terjadinya kasus Bank Century, beliau sedang menjabat jabatan Gubernur Bank Indonesia, untuk masa jabatan 22 Mei 2008 sampai dengan 16 Mei 2009.

${ }^{11}$ Rony Hanitiyo Soemitro, Metode Penelitian Hukum dan Juri Metri, (Jakarta: Ghalia Indonesia, 1994), hal 5.

${ }_{12}^{12}$ Peter Mahmud Marzuki, Penelitian Hukum, (Jakarta: Kencana, 2010), hal 93.

${ }^{13}$ Ibid. hal. 177.
} 
maupun fakta yang ada secara rinci, sistematis, dan menyeluruh sedangkan preskriptif merupakan pemecahan atas isu hukum yang diajukan dan secara etimologi berarti apa yang seharusnya ${ }^{14}$.

\section{HASIL DAN PEMBAHASAN}

Praperadilan menurut Pasal 1 Ayat 10 Undang-Undang Republik Indonesia Nomor 8 Tahun 1981 tentang Hukum Acara Pidana atau yang lebih dikenal dengan sebutan Kitab Undang-Undang Hukum Acara Pidana (KUHAP), adalah wewenang Pengadilan Negeri untuk memeriksa dan memutus menurut cara yang diatur dalam undang-undang ini:

a. Sah atau tidaknya suatu penangkapan dan atau penahanan atas permintaan tersangka atau keluarganya atau pihak lain atas kuasa tersangka;

b. Sah atau tidaknya penghentian penyidikan atau penghentian penuntutan atas permintaan demi tegaknya hukum dan pengadilan;

c. Permintaan ganti kerugian atau rehabilitasi oleh tersangka atau keluarganya atau pihak lain atas kuasanya yang perkaranya tidak diajukan ke pengadilan.

Ruang lingkup praperadilan sejatinya telah dibatasi dalam ketentuan Pasal 77 Kitab UndangUndang Hukum Acara Pidana (KUHAP), yang menyatakan bahwa Pengadilan Negeri berwenang untuk memeriksa dan memutus sesuai dengan ketentuan yang diatur dalam undang-undang ini tentang:

a. Sah atau tidaknya penangkapan, penahanan, penghentian penyidikan atau penghentian penuntutan;

b. Ganti kerugian dan atau rehabilitasi bagi seorang yang perkara pidananya dihentikan pada tingkat penyidikan atau penuntutan.

Namun ternyata perkembangan hukum telah menerobos batasan-batasan tersebut dan bahkan mendahului pembahasan Rancangan Kitab Undang-Undang Hukum Acara Pidana. Perluasan ruang lingkup praperadilan khususnya mengenai penetapan tersangka telah dimulai sebelum keluarnya Putusan Mahkamah Konstitusi (MK) Nomor 21/PUU-XII/2014. ${ }^{15}$ Setelah keluarnya Putusan tersebut, ruang lingkup praperadilan diperluas, yakni dengan adanya sah atau tidaknya penetapan tersangka. Setelah lahirnya putusan Mahkamah Konstitusi ini, maka permohonan praperadilan atas penetapan tersangka memiliki landasan hukum untuk diajukan ke pengadilan namun terdapat karakteristik khusus pengajuan praperadilan terkait penetapan tersangka, yakni: ${ }^{16}$

1) Penetapan tersangka tidak sah karena saksi-saksi, ahli, tersangka, penggeledahan, serta penyitaan dilakukan setelah penetapan tersangka sehingga tidak terpenuhi 2 (dua) alat bukti.

2) Permohonan praperadilan yang kedua kalinya mengenai penetapan tersangka tidak dapat dikategorikan sebagai nebis in idem karena belum menyangkut pokok perkara.

3) Penetapan tersangka atas dasar hasil pengembangan penyidikan terhadap tersangka lainnya dalam berkas berbeda adalah tidak sah.

\footnotetext{
14 Titon Slamet Kurnia dkk, Pendidikan Hukum, Ilmu Hukum dan Penelitian Hukum Di Indonesia:Sebuah Reorientasi, (Yogyakarta: Pustaka Pelajar, 2013), hal 129.

${ }^{15}$ Riki Perdana Raya Waruwu, Pasca Empat Putusan Mahkamah Konstitusi, Jakarta: Mahkamah Agung.go.id, diterbitkan pada tanggal 8 Agustus 2017. Diakses pada tanggal 27 Agustus 2018.

${ }^{16}$ Riki Perdana Raya Waruwu, Pasca Empat Putusan Mahkamah Konstitusi, Jakarta: Mahkamah Agung.go.id, diterbitkan pada tanggal 8 Agustus 2017. Diakses pada tanggal 27 Agustus 2018.
} 
Tata cara proses pemeriksaan praperadilan ini tercantum dalam Pasal 82 Kitab Undang-Undang Hukum Acara Pidana (KUHAP). Pemeriksaan praperadilan dilakukan secara cepat dan selambatlambatnya tujuh hari hakim harus sudah menjatuhkan putusannya, sebagaimana hal ini tercantum dalam Pasal 82 Ayat 1 huruf c Kitab Undang-Undang Hukum Acara Pidana (KUHAP).

Pemeriksaan praperadilan itu sendiri bisa gugur, artinya pemeriksaan praperadilan dihentikan sebelum putusan dijatuhkan. Adapun hal yang dapat mengugurkan pemeriksaan praperadilan adalah dalam hal suatu perkara sudah mulai diperiksa oleh Pengadilan Negeri, sedangkan pemeriksaan mengenai permintaan kepada praperadilan belum selesai, maka permintaan tersebut gugur. Hal ini tercantum dalam Pasal 82 Ayat 1 huruf d Kitab Undang-Undang Hukum Acara Pidana (KUHAP). Memperhatikan ketentuan itu gugurnya pemeriksaan praperadilan terjadi: ${ }^{17}$

- Apabila perkaranya telah diperiksa oleh Pengadilan Negeri;

- Pada saat perkaranya diperiksa Pengadilan Negeri, pemeriksaan praperadilan belum selesai.

Pada Pasal 83 Kitab Undang-Undang Hukum Acara Pidana (KUHAP) menyatakan bahwa:

1) Terhadap penetapan praperadilan dalam hal sebagaimana dimaksud dalam Pasal 79, Pasal 80, Pasal 81 tidak dapat dimintakan banding.

2) Dikecualikan dari ketentuan Ayat 1 adalah putusan praperadilan yang menetapkan tidak sahnya penghentian penyidikan atau penuntutan yang untuk itu dapat dimintakan putusan akhir ke Pengadilan Tinggi dalam daerah hukum yang bersangkutan.

Maka Pengadilan Tinggi yang memeriksa dan memutus upaya hukum banding sebagaimana dimaksud dalam Pasal 83 ayat 2 KUHAP, adalah bertindak sebagai pengadilan yang memeriksa dan memutus dalam tingkat akhir.

Dalam tahapan praperadilan hanya memeriksa dan memutus hal yang belum masuk pada materi perkara, jadi bukan dalam bentuk putusan perkara pidana, hanya mengenai sah atau tidaknya pejabat yang terlibat dalam pemeriksaan penyidikan dan penuntutan. ${ }^{18}$ Terkait akan hal itulah ada yang berpendapat bahwa permohonan kasasi atas putusan praperadilan tidak dapat di kasasi, dan juga ada yang berpendapat bahwa terdapat cukup alasan untuk mengajukan permohonan upaya hukum kasasi atas putusan praperadilan. Hal ini terjadi, bertitik tolak tentang materi yang diperiksa dan diputus lembaga praperadilan. Ada yang berpendirian, apa yang diperiksa dan diputus praperadilan bukan materi perkara pidana. ${ }^{19}$

Dalam Pasal 244 KUHAP menyatakan bahwa terhadap putusan perkara pidana yang diberikan pada tingkat terakhir oleh pengadilan lain selain dari pada Mahkamah agung, terdakwa atau penuntut umum dapat mengajukan permintaan pemeriksaan kasasi kepada Mahkamah Agung kecuali terhadap putusan bebas. Jelaslah bahwa permintaan kasasi hanya dapat diajukan terhadap putusan pengadilan yang berbentuk putusan perkara pidana. Menurut Yahya Harahap, oleh karena putusan praperadilan bukan mengenai perkara pidana, akan tetapi hanya tentang sah atau tidaknya tindakan pejabat yang terlibat dalam pemeriksaan penyidikan atau penuntutan, berarti putusan praperadilan benar-benar berada di luar ruang lingkup Pasal 244 KUHAP, oleh karena itulah putusan praperadilan tidak dapat dimintakan kasasi. ${ }^{20}$

\footnotetext{
${ }^{17}$ M. Yahya Harahap, Pembahasan Permasalahan Dan Penerapan KUHAP: Pemeriksaan Sidang Pengadilan, Banding, Kasasi, dan Peninjauan Kembali (Edisi Kedua), Jakarta: Sinar Grafika, 2000. Hal. 20.

${ }^{18}$ Andi Sofyan, Abd. Asis, Hukum Acara Pidana Suatu Pengantar, Jakarta: Prenadamedia Group, 2014. Hal. 197.

${ }^{19}$ Yahya Harahap, Pembahasan Permasalahan Dan Penerapan Kuhap Pemeriksaan Sidang Pengadilan, Banding, Kasasi, dan Peninjauan Kembali (Edisi Kedua), Jakarta: Sinar Grafika, 2000. Hal. 25.

${ }^{20} \mathrm{Ibid}$. Hal. 26.
} 
Terkait hal upaya hukum kasasi terhadap putusan praperadilan, Putusan Mahkamah Agung tanggal 10 Mei 1984, Reg. No. $680 \mathrm{~K} / \mathrm{Pid} / 1983$, dimana salah satu pertimbangannya menyatakan bahwa menurut yurisprudensi tetap terhadap putusan praperadilan tidak dapat dimintakan kasasi, sehingga permohonan kasasi dari pemohon kasasi harus dinyatakan tidak dapat diterima. Jelaslah bahwa hal ini semakin memperjelas pendirian Mahkamah Agung, bahwa permintaan kasasi terhadap putusan praperadilan tidak dimungkinkan dan dinyatakan tidak dapat diterima. Putusan ini sudah merupakan yurisprudensi tetap Mahkamah Agung. ${ }^{21}$

Sejalan dengan itu, dalam hal melakukan upaya hukum peninjauan kembali terhadap putusan praperadilan, KUHAP tidak mengaturnya, akan tetapi hal ini diatur dalam Peraturan Mahkamah Agung (PERMA) Republik Indonesia Nomor 4 Tahun 2016 tentang Larangan Peninjauan Kembali Putusan Praperadilan. Hal ini secara jelas dinyatakan dalam Bab III Larangan Peninjauan Kembali Putusan Praperadilan, Pasal 3, yang berbunyi sebagai berikut:

1) Putusan praperadilan tidak dapat diajukan peninjauan kembali.

2) Permohonan peninjauan kembali terhadap praperadilan dinyatakan tidak dapat diterima dengan penetapan ketua Pengadilan Negeri dan berkas perkara tidak dikirim ke Mahkamah Agung.

3) Penetapan ketua Pengadilan Negeri sebagaimana dimaksud pada ayat 1 tidak dapat diajukan upaya hukum.

Alasan pokok perkara yang mendasari permohonan pemeriksaan praperadilan yang dilakukan MAKI terhadap KPK, sebagaimana hal tersebut dinyatakan dalam putusan praperadilan, adalah untuk mengatasi ketidakpastian dan berlarut-larutnya penanganan perkara korupsi Bank Century yang memang diperlukan penemuan hukum dalam rangka mengisi kekosongan hukum atas kebuntuan penanganan perkara korupsi Bank Century oleh termohon dalam bentuk hakim mengabulkan permohonan praperadilan dan perintah hakim kepada termohon untuk melakukan proses hukum selanjutnya sesuai dengan ketentuan hukum dan peraturan perundang-undangan yang berlaku atas dugaan tindak pidana korupsi Bank Century dalam bentuk melakukan penyidikan dan menetapkan tersangka terhadap Boediono, Muliaman D Hadad, Raden Pardede dkk dan melanjutkan dengan pendakwaan dan penuntutan proses persidangan di Pengadilan Tindak Pidana Korupsi (Tipikor) Jakarta Pusat. Selain itu pihak pemohon juga menuangkan bunyi daripada Penjelasan Pasal 80 Kitab Undang-Undang Hukum Acara Pidana (KUHAP), bahwa Pasal ini bermaksud untuk menegakkan hukum, keadilan dan kebenaran melalui sarana pengawasan secara horizontal. Pihak pemohon juga mendalilkan bahwa pihak termohon, selaku KPK terbukti tidak melanjutkan penyidikan korupsi Bank Century dengan tidak menetapkan tersangka baru atas nama Boediono, Muliaman D Hadad, Raden Pardede dkk sehingga dengan demikian tindakan ini dipandang oleh pemohon praperadilan sebagai penghentian penyidikan korupsi Bank Century secara tidak sah dan melawan hukum. Selain itu dikarenakan penghentian penyidikan atas perkara tersebut tidak sah dan batal demi hukum, maka pihak pemohon praperadilan ini meminta termohon untuk melakukan proses hukum selanjutnya sesuai dengan ketentuan hukum yang berlaku. ${ }^{22}$

Putusan praperadilan nomor. 24/Pid/Pra/2018/PN.Jkt.Sel., yang memerintahkan kepada penyidik Komisi Pemberantasan Korupsi (KPK) agar menetapkan status tersangka terhadap Boediono, Muliaman D Hadad, Raden Pardede dkk atau melimpahkannya kepada Kepolisian atau Kejaksaan untuk agar dapat dilanjutkan dengan penyelidikan, penyidikan dan penuntutan dalam proses

\footnotetext{
${ }^{21}$ Ibid. hal. 27.

${ }^{22}$ Ringkasan dari Putusan Nomor: 24/Pid/Pra/2018/PN.JktSel. Bagian III tentang Alasan pokok perkara yang mendasari Permohonan Pemeriksaan Praperadilan. Hal 7-20.
} 
persidangan di Pengadilan Tindak Pidana Korupsi (Tipikor) Jakarta Pusat, menjadi sesuatu yang kontroversial, dikarenakan isi putusannya yang berada di luar ruang lingkup dari pada objek praperadilan itu sendiri.

Selain kedua pasal yang mengatur tentang praperadilan, yakni Pasal 1 Ayat 10 dan Pasal 77 KUHAP, putusan Mahkamah Konstitusi (MK) Nomor 21/PUU-XII/2014 telah memperluas ruang lingkup dari pada objek praperadilan itu sendiri, yakni terhadap sah atau tidaknya penetapan tersangka, sah atau tidaknya penggeledahan atau penyitaan yang dilakukan oleh penyidik dari aparat penegak hukum.

Dalam menyikapi hakim tunggal praperadilan yang telah memeriksa, mengadili serta memutus perkara praperadilan ini, yang mana putusan telah diucapkan dalam sidang yang terbuka untuk umum, yang akan tetapi isi dari pada putusan tersebut merupakan hal di luar ruang lingkup objek praperadilan itu sendiri, maka harus diingat bahwa ada suatu asas hukum yang menyatakan res judicata pro veritate habetur, yang menurut Sudikno Mertokusumo bahwa asas hukum tersebut memiliki arti, putusan hakim harus dianggap benar. ${ }^{23}$ Serupa dengan hal ini, bahwa dikenal prinsip hukum yang berlaku secara universal, yakni terkait dengan asas hukum tersebut yang dapat dikatakan bahwa perbuatan hakim dalam memeriksa dan memutus suatu perkara, yang mana putusan itu dijatuhkannya itu harus dianggap benar, apapun isi putusan tersebut, sampai ada putusan dari pengadilan yang lebih tinggi lainnya yang menganulirnya.

Sehubungan dengan hal tersebut, Pasal 24 Undang-Undang Dasar Negara Republik Indonesia 1945 (UUD NRI 1945), menyatakan bahwa kekuasaan kehakiman merupakan kekuasaan yang merdeka untuk menyelenggarakan peradilan guna menegakkan hukum dan keadilan. Adapun dalam Penjelasan Pasal 24 dan 25 UUD NRI 1945, dijelaskan bahwa kekuasaan kehakiman ialah kekuasaan yang merdeka artinya terlepas dari pengaruh kekuasaan pemerintah. Berhubungan dengan itu harus diadakan jaminan dalam undang-undang tentang kedudukannya para hakim. Dalam Pasal 1 ayat 1 Undang-Undang Republik Indonesia Nomor 48 tahun 2009 tentang Kekuasaan Kehakiman (UndangUndang Kekuasaan Kehakiman), berbunyi bahwa kekuasaan kehakiman adalah kekuasaan Negara yang merdeka untuk menyelenggarakan peradilan guna menegakan hukum dan keadilan berdasarkan Pancasila dan Undang-Undang dasar Negara Republik Indonesia Tahun 1945, demi terselenggaranya Negara Hukum Republik Indonesia. Hal ini tetntunya sejalan dengan semangat dari pada Pasal 3 Ayat 1 dan 2 Undang-Undang Kekuasaan Kehakiman, yang berbunyi sebagai berikut:

1) Dalam menjalankan tugas dan fungsinya, hakim dan hakim konstitusi wajib menjaga kemandirian peradilan.

2) Segala campur tangan dalam urusan peradilan oleh pihak lain di luar kekuasaan kehakiman dilarang, kecuali dalam hal-hal sebagaimana dimaksud dalam Undang-Undang Dasar Negara Republik Indonesia Tahun 1945.

Bahwa dalam hal ini, hakim ketika mengambil putusan dalam suatu perkara wajib didasarkan pada keyakinannya yang tentunya terlepas dari campur tangan pihak manapun, jadi hakim dalam menjalankan tugasnya wajib menjaga kemandirian peradilan. Hal ini pun juga terdapat dalam Pasal 183 Kitab Undang-Undang Hukum Acara Pidana (KUHAP) yang berbunyi hakim tidak boleh menjatuhkan pidana kepada seorang kecuali apabila sekurang-kurangnya dua alat bukti yang sah ia memperoleh keyakinannya bahwa suatu tindak pidana benar-benar terjadi dan bahwa terdakwalah yang bersalah melakukannya. Dan menurut penjelasan Pasal 183 Kitab Undang-Undang Hukum Acara Pidana (KUHAP) menyatakan bahwa ketentuan ini adalah untuk menjamin tegaknya kebenaran, keadilan dan kepastian hukum bagi seorang. Oleh karena atas keyakinannya itulah,

\footnotetext{
${ }^{23}$ Sudikno Mertokusumo, Penemuan Hukum Sebuah Pengantar, Yogyakarta: Liberty, 2006. Hal. 7.
} 
disamping adanya pembuktian, putusan hakim akan selalu dianggap benar, sesuai dengan asas hukum res judicata pro veritate habetur.

Terkait akan hal tersebut juga dikarenakan adanya asas hukum ius curia novit atau curia novit jus, yang dapat diartikan bahwa hakim dianggap mengetahui semua hukum sehingga pengadilan tidak boleh menolak memeriksa dan mengadili perkara. ${ }^{24}$ Prinsip inilah yang mendasari keberadaan Pasal 10 Undang-Undang Kekuasaan Kehakiman, yang berbunyi sebagai berikut:

1) Pengadilan dilarang menolak untuk memeriksa, mengadili, dan memutus suatu perkara yang diajukan dengan dalih bahwa hukum tidak ada atau kurang jelas, melainkan wajib untuk memeriksa dan mengadilinya.

2) Ketentuan sebagaimana dimaksud pada ayat 1 tidak menutup usaha penyelesaaian perkara perdata secara perdamaian.

Maksud dalam pasal tersebut adalah bahwa hakim dianggap memahami hukum secara mendalam dalam rangka memberikan pelayanan kepada setiap pencari keadilan yang memohon keadilan kepadanya. Dalam Pasal 10 Undang-Undang Kekuasaan Kehakiman yang mengacu kepada asas hukum ius curia novit tersebut, menurut Yahya Harahap, bahwa hakim dianggap mengetahui dan memahami segala hukum. Dengan demikian, hakim yang berwenang menentukan hukum mana yang harus diterapkan sesuai dengan materi pokok perkara, oleh karena itulah hal tersebut menjadi kewajiban dan kewenangan hakim. Para pihak tidak wajib membuktikan hukum apa yang harus diterapkan, karena hakim dianggap mengetahui segala hukum. ${ }^{25}$ Akan tetapi prinsip atau asas hukum tersebut pada dasarnya hanya bersifat teori dan asumsi semata, dikarenakan seorang hakim juga layaknya seorang manusia biasa yang memiliki keterbatasan walaupun di satu sisi ia memiliki pengetahuan dan pengalaman yang luas. Karena keterbatasan itulah seorang hakim tidaklah mungkin untuk mengetahui segala hukum yang begitu luas dan kompleks. Namun demikian prinsip ini selalu digunakan untuk menguatkan fungsi dan kewajiban hakim agar dapat memeriksa, mengadili serta memutus suatu perkara dengan baik berdasarkan hukum. Oleh karena mengetahui serta memahami secara mendalam mengenai seluk beluk hukum yang luas dan kompleks itulah maka setiap putusan hakim akan selalu dianggap benar sepanjang tidak ada putusan lainnya dari pengadilan yang lebih tinggi yang merubah ataupun membatalkannya.

Bahwa terkait dengan putusan praperadilan Nomor 24/Pid/Pra/2018/PN.Jkt.Sel yang diputus oleh hakim tunggal Effendi Mukhtar, yang isinya memerintahkan Komisi Pemberantasan Korupsi untuk menetapkan status tersangka terhadap Boediono, Muliaman D Hadad, Raden Pardede dkk atau melimpahkannya kepada Kepolisian dan atau Kejaksaan untuk dilanjutkan dengan penyelidikan, penyidikan, dan penuntutan dalam proses persidangan di Pengadilan Tindak Pidana Korupsi Jakarta Pusat, menurut Abdullah ${ }^{26}$ merupakan persoalan dan independensi hakim, dan merupakan sebuah penemuan hukum oleh hakim, yang meski demikian akan dilakukan pengujian secara filosofis dan teori hukum oleh masyarakat, khususnya akademisi ataupun praktisi. ${ }^{27}$ Adapun menurut Gayus Lumbuun $^{28}$, bahwa putusan praperadilan tersebut sebagaimana tercantum dalam Pasal 77 Kitab Undang-Undang Hukum Acara Pidana (KUHAP) serta perluasannya yang sebagaimana diputus oleh Mahkamah Konstitusi dalam putusan Nomor 21/PUU-XII/2014, dinyatakan juga bahwa semua

${ }^{24}$ Yahya Harahap, Hukum Acara Perdata tentang Gugatan, Persidangan, Penyitaan, Pembuktian dan Putusan Pengadilan. Jakarta: Sinar Grafika, 2016. Hal. 821.

${ }^{25} \mathrm{Ibid}$. hal 821.

${ }^{26}$ Kepala Biro Hukum dan Hubungan Masyarakat (Humas) Mahkamah Agung Republik Indonesia.

${ }^{27}$ Isi putusan Prapreadilan Kasus Century Yang Menuai Kontroversi dari https://nasional.kompas.com, diakses pada tanggal 2 September 2018.

${ }^{28}$ Mantan Hakim Agung. 
putusan hakim itu perlu dan wajib dilaksanakan ${ }^{29}$. Hal ini merupakan bentuk nyata dari pada asas hukum res judicata pro veritate habetur.

\section{KESIMPULAN DAN SARAN KESIMPULAN}

Putusan praperadilan Nomor 24/Pid/Pra/2018/PN.Jkt.Sel yang isi putusannya berada di luar ketentuan yang diatur dalam Pasal 1 Ayat 10 dan Pasal 77 KUHAP, maka haruslah putusan tersebut wajib untuk dilaksanakan. Hal ini diperkuat dengan asas hukum res judicata pro veritate habetur yang menyatakan bahwa putusan hakim selalu dianggap benar. Terkait hal itulah terdapat mekanisme upaya hukum terhadap putusan hakim, hal ini untuk memperbaiki putusan yang dianggap salah oleh pihak tertentu bila ada suatu kekeliruan hakim dalam memberikan putusan dan juga untuk mengedepankan kepastian hukum, keadilan serta kemanfaatan hukum. Sejalan dengan asas hukum tersebut yang telah dinyatakan oleh Gayus Lumbuun bahwa semua putusan hakim wajib untuk dilaksanakan, sebab tidak ada lembaga negara lainnya yang dapat memutus sesuatu selain dari pada badan peradilan itu sendiri.

\section{SARAN}

Terkait dengan kesimpulan di atas, bahwa sudah seharusnya Komisi Pemberantasan Korupsi segera melakukan proses hukum selanjutnya terhadap pihak-pihak yang menjadi objek dan disebutkan dalam putusan praperadilan tersebut. Hal ini dikarenakan bahwa putusan pengadilan wajib untuk dilaksanakan demi terwujudnya apa yang dinamakan dengan fungsi hukum, yakni kepastian, keadilan, serta kemanfaatan hukum.

\section{REFERENSI}

\section{Buku:}

Hamzah, Andi. Hukum Acara Pidana Indonesia (Edisi Kedua). Jakarta: Sinar Grafika, 2015.

Harahap, M. Yahya. Pembahasan Permasalahan Dan Penerapan KUHAP: Pemeriksaan Sidang Pengadilan, Banding, Kasasi, dan Peninjauan Kembali (Edisi Kedua), Jakarta: Sinar Grafika, 2000.

Harahap, Yahya. Hukum Acara Perdata tentang Gugatan, Persidangan, Penyitaan, Pembuktian dan Putusan Pengadilan. Jakarta: Sinar Grafika, 2016.

Kurnia dkk, Titon Slamet. Pendidikan Hukum, Ilmu Hukum dan Penelitian Hukum Di Indonesia:Sebuah Reorientasi, Yogyakarta: Pustaka Pelajar, 2013.

Marzuki, Peter Mahmud Marzuki. Penelitian Hukum, Jakarta: Kencana, 2010.

Mertokusumo, Sudikno. Penemuan Hukum Sebuah Pengantar, Yogyakarta: Liberty, 2006.

Pangaribuan, Luhut M.P. Hukum Acara Pidana: Surat-Surat Resmi di Pengadilan oleh Advokat, Praperadilan, Eksepsi, Pledoi, Duplik, Memori Banding, Kasasi, Peninjauan Kembali. Jakarta: Djambatan, 2005.

Prodjodikoro, Wirjono. Hukum Acara Pidana di Indonesia. Bandung: Sumur Bandung, 1974.

Soemitro, Rony Hanitiyo. Metode Penelitian Hukum dan Juri Metri, Jakarta: Ghalia Indonesia, 1994. Sofyan, Andi, Abd. Asis. Hukum Acara Pidana Suatu Pengantar. Jakarta: Prenadamedia Group, 2014.

\footnotetext{
${ }^{29}$ Indonesian Lawyers Club TV One, Berwenangkah Praperadilan Menetapkan Boediono Tersangka? Ditayangkan pada
} 17 April 2018. 


\section{Jurnal:}

Riki Perdana Raya Waruwu, Pasca Empat Putusan Mahkamah Konstitusi, Jakarta: Mahkamah Agung.go.id, diterbitkan pada tanggal 8 Agustus 2017.

\section{Peraturan:}

Undang-Undang Dasar Negara Republik Indonesia 1945.

Undang-Undang Republik Indonesia Nomor 8 Tahun 1981 tentang Hukum Acara Pidana (KUHAP). Undang-Undang Republik Indonesia Nomor 48 Tahun 2009 Tentang Kekuasaan Kehakiman.

Peraturan Mahkamah Agung (PERMA) Republik Indonesia Nomor 4 Tahun 2016 Tentang Larangan Peninjauan Kembali Putusan Praperadilan.

Putusan Nomor 24/ Pid.Pra/2018 PN.Jkt.Sel.

Putusan Mahkamah Konstitusi (MK) Nomor 21/PUU-XII/2014.

Putusan Mahkamah Agung tanggal 10 Mei 1984, Reg. No. 680 K/Pid/1983.

Internet:

https://nasional.kompas.com.

\section{Media Diskusi:}

Indonesia Lawyers Club TV One 